\title{
Knowledge Management and Organizational Activity Results in a Sample of Companies in Bogota
}

\author{
César A. Bernal ${ }^{1} \&$ German Fracica $^{2}$ \\ ${ }^{1}$ International School of Economics and Administrative Sciences, Universidad de La Sabana, Bogotá, Colombia \\ ${ }^{2}$ Graduate Professor, Graduate Institute - Forum, Universidad de La Sabana, Bogotá, Colombia \\ Correspondence: César A. Bernal, International School of Economic and Administrative Sciences, Universidad \\ de La Sabana, Bogotá, Colombia, Campus del puente del Común, Oficina 217, Edificio E2, Km 7, Autopista \\ Norte de Bogotá, Chía, Cundinamarca, Colombia. Tel: 571-861-5555. E-mail: cesar.bernal@unisabana.edu.co
}

Received: October 3, 2012 Accepted: October 31, 2012 Online Published: April 24, 2013

doi:10.5539/par.v2n1p46 URL: http://dx.doi.org/10.5539/par.v2n1p46

\begin{abstract}
Knowledge Management (KM) especially in developing countries in recent years has generated much interest to be incorporated as a strategy to enhance business competitiveness. However the results of several recent studies on the subject especially in Europe indicate that it cannot be concluded on the direct causal relationship between knowledge management and the results of the business activities. In this regard, the results of this study performed with a sample of 386 managers from 58 large and medium size enterprises in Bogota evidence the absence of direct relationship between these variables under study. This may result due to the fact that the impact of KM in the results of enterprises depends also on the specifics of each organization and/or the fact that their results are consequence of a number and not only one variable of the enterprise administrative field.
\end{abstract}

Keywords: competitiveness, knowledge management, strategy and strategic resource

\section{Introduction}

Today, it is recognized the acquired relevance of knowledge management as a strategic resource to increase competitiveness in enterprises of developing countries as a strategy to face the challenges of the business environment characterized by an each time greater globalization, competitively, uncertainty and changes from different sources. However, in the same order of ideas, the results of recent studies on the subject, mainly in Europe (Prieto and Revilla, 2000; Rivero, 2002 and Donate y Guadamillas, 2009) deviate from the tenets of those who maintain the existence of a direct relationship between knowledge management and the positive results of organizations (Drucker, 1999; Nonaka and Takeuchi, 1999; Grant, 1996, Nonaka and Teece, 2001; Navas and Nieto, 2003).

According to Rivero (2002) Prieto and Revilla (2000) and Donate and Guadamillas (2009), when studying the impact of knowledge management in obtaining the organizational objectives, diverse studies show that organizations can obtain different quotas of results depending on the function of the model (point of view) and/or knowledge management tool being used and/or the strategy implemented in this field.

Also, Rodríguez (2006), taking in consideration the existence of different perspectives for the design, development and evaluation of programs in this field, considers necessary that when valuating the impact of knowledge management activities in the results of organizations is taken in consideration that each point of view according to its objective and the tools used influences differently the results of each organization.

In this regard, MacAdam and MacCreedy (1999), suggest that when designing and implementing any knowledge management program is necessary to take in consideration the point of view that wants to be given to the activities of knowledge management and the pretended objectives of that management so there is correspondence between the point of view and the predicted organizational results, given the fact that each point of view affects in a different way the results of each organization.

So, for Prieto and Revilla (2004) and Donate and Guadamillas (2009), as consequence of the diversity of the points of view that exist today refereed to knowledge management, it is complex the study and evaluation in this field. For these authors, as for the ones mentioned before, each point of view has different requirements and implications in their application and therefore in the dynamic and the particular results of organizations. 
According to Prieto and Revilla (2004) and Donate and Guadamillas (2009), recent studies en Europe oriented to evaluate the role of knowledge management in the results of organizations, indicate that organizations that perform knowledge management where it is emphasized the relevance of people as owners, creators and users of knowledge as a sustainable strategic resource for competitiveness tend to show a better positive relationship between knowledge management and their activity results than those that have a technocratic orientation, meaning, that put their emphasis in the appropriation and uses of information and communication technologies (ICT's) as generators of organizational value.

For the case of similar studies in United States of America companies according to Alavi and Tiwana (2003) knowledge management programs with emphasis in appropriation and intensive use of information and communication technologies (ITC's) tend to have higher impact in the results of organizations that those with emphasis in social factors. However, for these authors, the models that integrate harmoniously the two approaches tend to generate greater impact in the organizational dynamic in their results of activity than those models that emphasize in one or other model.

However, holistic view of the approaches to knowledge management scholars such as Leonard and Sensiper (1998), Rivero (2002) and MacAdan and Reid (2001), Prieto and Revilla (2004) and Donate y Guadamillas (2009) among others, do not hesitate to say that is complex to generalize the direct relationship between knowledge management programs and the results of organizations, because empiric evidence shows the diversity of results many times contradictory.

Authors such as Davenport, Delong and Beers (1998), Nonaka and Takeuchi (1999) and Drucker (2001), Lee y Choi (2003), Lundvall.y Nielsen (2007). Zack, Mckeen,y Singh (2009), Fugate, Stank y Mentzer (2009), Huang y Shih (2009) among others, with the opposite opinion do not hesitate to point out the direct positive relationship between knowledge management and the positive results of organizations regardless of the approach given to this management and also emphasize that it is knowledge management the responsible in determining sustained competitiveness in organizations of any area in the current organizational environment characterized by an increased competitiveness, complexity and uncertainty.

Summarizing, as consequence of the disagreement in the results of the studies on the topic of knowledge management and the results of the enterprise activity, it was planned this study with the purpose of knowing the situation on the subject in the case of a sample of enterprises in Bogota. Therefore, the question that oriented the study was: the activities of knowledge management performed by the companies have direct relationship with the results of their organizational results?

\section{Method}

This study was conducted through the application of surveys to 386 executives from 58 large and medium companies from different sectors of the economic activity and legal nature, located in the city of Bogota and its influence area. The 58 companies from which the managers that participated in this study are part of are a sample of a total of 91 companies - medium and big - located in the city of Bogota, which in previous research about knowledge management were performing during the last five years knowledge management (Blanco and Bernal 2009 and Bernal, Turriago and Sierra, 2010).

To obtain the information was applied the survey questionnaire called "Impact of knowledge management in the results of organizations" and developed based on the studies made by Prieto and Revilla (2004) and Donate and Guadamillas (2008). The questionnaire, which has 23 statements, allowed to gather information about the basic activities of knowledge management by organizations and the results of the organizational activity for the period studied. For the answers to the statements was used the Likert scale with possibilities of answers from 1 to 5 , where 5 meant high impact.

Interviews were made personally to several managers of each one of the 58 companies with the purpose of getting a general vision of the activities of these companies and their result achievement. This was because it is the managers who have the knowledge of the companies and are the responsible for making the strategic decisions. Gathering of information through interviews for this study was made in the period of time between March 2010 and February 2011.

For the analysis of the results were performed frequency calculations for categorical variables y hypothesis tests of variable independence and Spearman's correlation of coefficient calculation. Hypothesis tests were made to prove the existence of statistic independence relationships between the variables of the study under the following parameters:

1. Hypothesis to contrast: 
$H_{\mathrm{o}}$ : Variable $\mathrm{X}_{\mathrm{i}}$ and variable $\mathrm{X}_{\mathrm{j}}$ are independent

$\mathrm{H}_{1}$ : Variables $\mathrm{X}_{\mathrm{i}}$ and $\mathrm{X}_{\mathrm{j}}$ are dependents or are related

Where:

$\mathrm{X}_{\mathrm{i}}$ corresponds to the activities of knowledge management (identification, registry, sharing, creation and use of relevant knowledge)

$\mathrm{X}_{\mathrm{j}}$ corresponds to the results of organizations (changes or improvements in the products or services offered, in processes, in managerial activities, in activities related to marketing; in activities related with taking care of the environment, the development of human and organizational potential and the profit increase).

Statistical test: Chi- Pearson's square with correction factor for continuity.

2. Significance level: $95.0 \%$

3. Decision rule: Region of rejection for these tests: $3.84<\mathrm{X}^{2}<\infty$

For a confidence level of $95 \%$ the critical value for the coefficients of Spearman's correlation is 0.478

\section{Results}

Table 1. Activities of knowledge management according to percentage of companies that apply them

\begin{tabular}{ll}
\hline Activities of knowledge management & $\begin{array}{l}\text { Percentage of } \\
\text { companies }\end{array}$ \\
\hline Formal programs to improve worker skills work related. & $32.8 \%$ \\
Formal programs to improve worker development. & $32.8 \%$ \\
Systematic identification of knowledge and capabilities of organizations. & $22.4 \%$ \\
Registry and sharing of relevant information to achieve organizational objectives. & $25.9 \%$ \\
Motivation to share with coworkers' experiences and knowledge related to work & $29.3 \%$ \\
activities. & \\
Generation of new ideas and knowledge for an increased work performance. & $20.7 \%$ \\
\hline
\end{tabular}

Source: Author's calculations

Table 2. Percentage of companies that perceived a high impact of the knowledge management in their results

\begin{tabular}{ll}
\hline Impact of the knowledge management in their results & $\begin{array}{l}\text { Percentage } \\
\text { companies }\end{array}$ \\
\hline Improvement in enterprise processes & $37.9 \%$ \\
Improvement in products or services offered & $22.4 \%$ \\
Improvement in the environment & $13.8 \%$ \\
Reduces the consumption of raw materials & $12.1 \%$ \\
Development of human and organizational potential & $29.3 \%$ \\
Improvement in organizational climate & $29.5 \%$ \\
Improvement in the relationship with customers & $37.9 \%$ \\
Improvement in the relationship with the external environment & $31.0 \%$ \\
Increased market positioning & $36.3 \%$ \\
Improvement in organizational processes & $25.9 \%$ \\
Access to new markets & $25.8 \%$ \\
Increased profitability of the company & $36.2 \%$ \\
Increased sales & $22.4 \%$ \\
Increased assets & $18.9 \%$ \\
\hline
\end{tabular}

Source: Author's calculations. 
Table 3. Interdependence relationships between the activities of knowledge management and organizational results

\begin{tabular}{|c|c|c|c|c|c|c|}
\hline $\begin{array}{l}\text { Knowledge management } \\
\left(\mathrm{X}_{\mathrm{i}}\right) \\
\left(\mathrm{J}_{\mathrm{j}}\right) \\
\text { Results of the company }\end{array}$ & $\begin{array}{l}\text { Training } \\
\text { programs }\end{array}$ & $\begin{array}{l}\text { Development } \\
\text { programs }\end{array}$ & $\begin{array}{l}\text { Process of } \\
\text { identifying } \\
\text { knowledge }\end{array}$ & $\begin{array}{l}\text { Registry } \\
\text { and access } \\
\text { to } \\
\text { knowledge }\end{array}$ & $\begin{array}{l}\text { Culture to } \\
\text { share } \\
\text { knowledge }\end{array}$ & $\begin{array}{l}\text { Conditions } \\
\text { to create } \\
\text { knowledge }\end{array}$ \\
\hline $\begin{array}{l}\text { Improvement or change } \\
\text { in the processes of the } \\
\text { company }\end{array}$ & $\begin{array}{l}9.31 \\
(0.439)\end{array}$ & $3.6(0.29)$ & $5.4(0.35)$ & $\begin{array}{l}12.9 \\
(0.512)\end{array}$ & $\begin{array}{l}12.9 \\
(0.51)\end{array}$ & $\begin{array}{l}1.69 \\
(0.22)\end{array}$ \\
\hline $\begin{array}{l}\text { Improvement or change } \\
\text { in products or services }\end{array}$ & $\begin{array}{l}12.36 \\
(0.51)\end{array}$ & $0.7(0.15)$ & $\begin{array}{l}1.43 \\
(0.207)\end{array}$ & $5.09(0.31)$ & $\begin{array}{l}3.46 \\
(0.29)\end{array}$ & $\begin{array}{l}1.68 \\
(0.23)\end{array}$ \\
\hline $\begin{array}{l}\text { Improvement in the } \\
\text { impact on the } \\
\text { environment }\end{array}$ & $\begin{array}{l}0.509 \\
(0.147)\end{array}$ & $0.51(0.15)$ & $\begin{array}{l}2.43 \\
(0.26)\end{array}$ & $4.47(0.34)$ & $\begin{array}{l}0.017 \\
(0.07)\end{array}$ & $\begin{array}{l}3.01 \\
(0.29)\end{array}$ \\
\hline $\begin{array}{l}\text { Reduction in the } \\
\text { consumption of raw } \\
\text { materials }\end{array}$ & $\begin{array}{l}1.07 \\
(0.19)\end{array}$ & $3.6(0.31)$ & $\begin{array}{l}3.4 \\
(0.309)\end{array}$ & $2.42(0.26)$ & $\begin{array}{l}1.64 \\
(0.23)\end{array}$ & $\begin{array}{l}1.09 \\
(0.23)\end{array}$ \\
\hline $\begin{array}{l}\text { Development of the } \\
\text { human and organizational } \\
\text { potential }\end{array}$ & $\begin{array}{l}9.18 \\
(0.44)\end{array}$ & $9.18(0.48)$ & $\begin{array}{l}6.51 \\
(0.38)\end{array}$ & $\begin{array}{l}11.30 \\
(0.48)\end{array}$ & $\begin{array}{l}22.04 \\
(0.66)\end{array}$ & $\begin{array}{l}4.15 \\
(0.326)\end{array}$ \\
\hline $\begin{array}{l}\text { Improvement in the } \\
\text { organizational climate }\end{array}$ & $\begin{array}{l}3.25 \\
(0.28)\end{array}$ & $0.38(0.11)$ & $3.4(0.29)$ & $\begin{array}{l}7.308 \\
(0.39)\end{array}$ & $\begin{array}{l}8.2 \\
(0.418)\end{array}$ & $\begin{array}{l}0.49 \\
(0.13)\end{array}$ \\
\hline $\begin{array}{l}\text { Improvement in the } \\
\text { relationships } \\
\text { customers }\end{array}$ & $\begin{array}{l}6.12 \\
(0.36)\end{array}$ & $1.75(0.21)$ & $2.8(0.26)$ & $\begin{array}{l}12.89 \\
(0.51)\end{array}$ & $\begin{array}{l}17.6 \\
(0.61)\end{array}$ & $\begin{array}{l}1.69 \\
(0.28)\end{array}$ \\
\hline $\begin{array}{l}\text { Improvement in the } \\
\text { relationship with the } \\
\text { external environment }\end{array}$ & $\begin{array}{l}4.75 \\
(0.326)\end{array}$ & $7.7(0.41)$ & $2.8(0.26)$ & $9.86(0.48)$ & $\begin{array}{l}10.61 \\
(0.48)\end{array}$ & $\begin{array}{l}3.78 \\
(0.31)\end{array}$ \\
\hline $\begin{array}{l}\text { Improvement in market } \\
\text { positioning }\end{array}$ & $\begin{array}{l}10.07 \\
(0.47)\end{array}$ & $4.4(0.35)$ & $\begin{array}{l}14.4 \\
(0.54)\end{array}$ & $10.0(0.47)$ & $\begin{array}{l}10.3 \\
(0.48)\end{array}$ & $\begin{array}{l}7.85 \\
(0.48)\end{array}$ \\
\hline $\begin{array}{l}\text { Improvement in } \\
\text { administrative processes }\end{array}$ & $\begin{array}{l}12.74 \\
(0.51)\end{array}$ & $1.02(0.17)$ & $\begin{array}{l}5.10 \\
(0.34)\end{array}$ & $\begin{array}{l}10.01 \\
(0.47)\end{array}$ & $\begin{array}{l}11.34 \\
(0.48)\end{array}$ & $\begin{array}{l}3.15 \\
(0.28)\end{array}$ \\
\hline Access to new markets & $\begin{array}{l}2.73 \\
(0.26)\end{array}$ & $0.41(0.09)$ & $5.1(0.34)$ & $\begin{array}{l}10.01 \\
(0.47)\end{array}$ & $\begin{array}{l}11.34 \\
(0.48)\end{array}$ & $6.3(0.48)$ \\
\hline $\begin{array}{l}\text { Improvement } \\
\text { profitability }\end{array}$ & $\begin{array}{l}4.44 \\
(0.32)\end{array}$ & $0.9(0.16)$ & $\begin{array}{l}1.38 \\
(0.19)\end{array}$ & $\begin{array}{l}10.01 \\
(0.47)\end{array}$ & $\begin{array}{l}10.3 \\
(0.68)\end{array}$ & $\begin{array}{l}0.61 \\
(0.15)\end{array}$ \\
\hline Increase in sales & $\begin{array}{l}12.36 \\
(0.51)\end{array}$ & $2.26(0.24)$ & $8.8(0.44)$ & $8.8(0.44)$ & $\begin{array}{l}3.46 \\
(0.236)\end{array}$ & $\begin{array}{l}1.98 \\
(0.24)\end{array}$ \\
\hline Increase in assets & $\begin{array}{l}7.73 \\
(0.412)\end{array}$ & $7.73(0.412)$ & $\begin{array}{l}12.7 \\
(0.519)\end{array}$ & $12.7(0.52)$ & $\begin{array}{l}2.84 \\
(0.268)\end{array}$ & $\begin{array}{l}3.38 \\
(0.29)\end{array}$ \\
\hline
\end{tabular}

Source: Author's calculations

The results of the study indicate that (with a level of confidence of $95.0 \%$ in Sperman's correlation coefficient test) in les than $33 \%$ of participating enterprises in the study there is significative statistical relationship between the activities of knowledge management -identification and acquisition, registry, socialization and sharing, creation and use of relevant knowledge - and the positive results of enterprises, especially to maintain o gain market share and/or maintain or increase profitability.

The other hand, the study indicates that regards to the activities related with knowledge management performed by the set of enterprises involved in the study during the last years, formal training programs for work and 
development of the worker (32.8\%), level of motivation of people to share knowledge and experience with colleagues $(29.3 \%)$, were the activities more present in these companies. While those related with the generation of new knowledge for organizational performance $(20 \%)$, among with processes of systematic identification of knowledge and the capacities of the enterprise $(22.4 \%)$ were the least present.

Regarding the impact of knowledge management activities in the results of organizational activities, results indicate that $37.9 \%$ of executives consider that those activities performed by their companies had high and favourable impact in the improvement of processes in the enterprise and in the relations with customers and, $36.6 \%$ state that the benefits of these activities have been reflected in the profitability and the positioning in the market. While the lower impacts are in the reduction in raw materials (12.1\%), improvements in environmental impact (13.8\%) and improvements in products or services (22.4\%).

While related to the analysis of statistical interdependent relationships between knowledge management and organizational results (with a significance level of 95.0\%), data indicates that in general none of the activities of that management performed by companies in the last five years show a direct interdependence relationship with the results of the organizational activity as can be seen in table 3 .

\section{Discussion of Results y Conclusions}

In general, the results of the study indicate that although managers of companies consider that in companies knowledge management is made, reality shows that this management is only reflected in very limited activities and without much relevance for the organizations. This can be in a great extent due the lack of clarity that managers interviewed have of the concept and the importance of a systematic knowledge management to boost the competitive capacity of companies. Evidence of this affirmation is reflected when managers are asked if the companies where they work is made and given relevance to knowledge management and their answer tends to be affirmative.

On other hand, data of the study also indicates that in general for the sample of companies analyzed there is no interdependence relationship between the activities of knowledge management that they said to perform in companies in the last five years with their organizational performance. From the theoretical perspective, the explanation of these results is explained by authors such as Prieto and Revilla (2000), Rivero (2002) and Donate and Guadamillas (2009) who consider that it cannot be generalized the existence of a relationship between the activities of knowledge management performed by companies with their organizational results. From the empirical point of view, this explanation can be caused by the lack of clarity on the topic by the managers and a impact indicator culture in the context of organizations studied.

Based in previous statements, the results of this study have to be referent of reflection by academics who study the topic for decision making processes of organizational executives and government responsible for promoting competitiveness because, they indicate that the lack of knowledge management activities in a systematic manner the dynamic of the company and their results are affected positively, depending this mainly on the particular characteristics of each company and the strategies that with this purpose implement their executives.

It is worth clarifying that for a more conclusive evidence on the subject particularly in companies in developing countries, as is the case of companies in Colombia, is recommended more representative studies in the size of the sample and in various contexts (more samples in companies in more cities of a same country, but also in several countries that allow comparisons). It is also necessary perform studies that allow the comparison the results for each one of the main focuses pointed in the theoretical review of the subject (knowledge management with emphasis in people, with emphasis in technologies or integral emphasis). This would give evidence to explain the diversity in the results related to the relationship between knowledge management and organizational effectiveness.

Finally, it is important to note that one of the main weaknesses of this study is that the sample of the participating companies when not proving systematic processes of true knowledge management cannot be a referent for formulating conclusions applicable to organizational environments with more experience on the subject.

\section{References}

Alavi, M., \& Tiwana, A. (2003). Knowledge Management: The Information Technology Dimension. In M. Easterby-Smith, \& M. A. Lyles (Eds.), Organizational Learning and Knowledge Management (pp. 104-121). London: Blackwell Publishing.

Bernal, C., Turriago, A., \& Sierra, H. (2010). Aproximación a la medición de la gestión del conocimiento empresarial. Ad-Minister, Universidad Eafi, 16, 30-49. 
Blanco, C., \& Bernal, C. (2009). Percepciones sobre la gestión del conocimiento por parte de una muestra de directivos de grandes y medianas empresas en Bogotá. Cultura, Tecnología y Patrimonio, 4(7), 81-98.

Centro para el Desarrollo Tecnológico Industrial- CDTI. (2009). Impacto de la I+D+I en el sector productivo español. Consultado 5 de agosto de 2010. Retrieved from http://www.madrimasd.org/empleo/documentos/doc/Impacto_de_la_IDi_sector_productivo_espanol_cdti.p $\mathrm{df}$

Davenport, T., Delong, D., \& Beers, M. (1998). Successful Knowledge Management Projects. Sloan Management Review, 39(2), pp. 43-57.

Donate, M., \& Guadamillas, F. (2008). La Relación entre la Postura Tecnológica de la Empresa y su Estrategia de Conocimiento. Un Análisis de su Efecto en los Resultados. Revista Europea de Dirección y Economía de la Empresa, 17(4), 29-54.

Donate, M., \& Gaudamillas, F. (2009). Estrategia de gestión del conocimiento y actitud Innovadora en empresas de castilla-la mancha. Un Estudio exploratorio. Investigaciones Europeas de Dirección y Economía de la Empresa, 16(1), 31-54. Retrieved from http://www.aedem-virtual.com/articulos/iedee/v16/161031.pdf

Drucker, P. (1999). Knowledge-Worker Productivity: the Biggest Challenge. California Management Review, 41(2), 79-94. http://dx.doi.org/10.2307/41165987

Drucker, P. (2001). The next society: a survey of the near future. The Economist, pp. 3-21.

Fugate, B., Stank, T., \& Mentzer, J. (2009). Linking improved knowledge management to operational and organizational performance. Journal of Operations Management, 27, 247-264. http://dx.doi.org/10.1016/j.jom.2008.09.003

Grant, R. M. (1996). Toward Knowledge Based Theory of the Firm. Strategic Management Journal, 17, 109-122.

Huang, P., \& Shih, L. (2009). Effective environmental management through environmental knowledge management. International Journal of Environmental Science and Technology, 6(1), 35-50.

Lee, H., \& Choi, B. (2003). Knowledge management enablers, processes, and organizational performance:an integrative view and empirical examination. Journal of Management Information Systems, 20(1), 179-228.

Leonard, D., \& Sensiper, S. (1998). The concept of "BA"-Building a foundation for knowledge creation. California Management Review, 40(3), 73-97.

Lundvall, B., \& Nielsen, P. (2007). Knowledge management and innovation performance. International Journal of Manpower, 28(3/4), 207-223. http://dx.doi.org/10.1108/01437720710755218

MacAdam, R., \& MacCreedy, S. (1999). A critical review of knowledge management models. The Learning Organization, 6(3), 91-100. http://dx.doi.org/10.1108/09696479910270416

MacAdan, R., \& Reid, R. (2001). SME and large organization perception of knowledge Management: Comparisons and contrast. Journal of knowledge management, 5(3).

Nonaka, I., \& Takeuchi, H. (1999). La organización creadora de conocimiento: cómo las compañias japonesas crean la dinámica de la innovación. México: Oxford.

Nonaka, I., \& Teece, D. J. (2001). Research Directions for Knowledge Management. In I. Nonaka, \& D. J. Teece (Eds.), Managing Industrial Knowledge: Creation, Transfer and Utilization (pp. 330-335). Sage, London. http://dx.doi.org/10.4135/9781446217573.n17

Prieto, I., \& Revilla, E. (2004). La naturaleza dual de la gestión del conocimiento. Revista Latinoamericana de Administración. Universidad de los Andes, Bogotá, Colombia, (32), pp. 47-76. Retrieved from http://redalyc.uaemex.mx/pdf/716/71603204.pdf

Rivero, C. (2002). Pautas para comprender e implantar la gestión del conocimiento. Madrid: Fundación Escuela de Ingenieros de Bilbao - Socintec,

Rodríguez, A. (2006). Un modelo integral para evaluar el impacto de la transferencia de conocimiento interorganizacional en el desempeño de la firma. Estudios Gerenciales, 95, 37-50. Retrieved from http://bibliotecadigital.icesi.edu.co/biblioteca_digital/bitstream/item/356/1/augusto_rodriguez_modelo_inte gral.pdf 
Zack, M., Mckeen, J., \& Singh, S. (2009). Knowledge management and organizational performance: an exploratory analysis. Journal of http://dx.doi.org/10.1108/13673270910997088

Knowledge Management, 13(6), 392-409. 